\title{
THE IDENTIFICATION OF THE WHITE-BELLIED SEA EAGLE (Haliaeetus leucogaster) BASED ON MORPHOLOGICAL CHARACTERISTICS
}

\author{
Riri Wiyanti Retnaningtyas ${ }^{1}$, Windri Hermadhiyanti' ${ }^{1}$, Dwi Anggorowati Rahayu², \\ and Dwi Listyorini ${ }^{1}$ \\ ${ }^{1}$ Department of Biology, Faculty of Mathematic and Natural Sciences, State University of Malang, Jl. Semarang 5, \\ Malang, Indonesia 65145, ${ }^{2}$ Biology Departement, Post Graduate Program, Brawijaya University, Jl. Veteran, \\ Malang, Indonesia \\ E-mail: hermadhiyantiwindri@gmail.com: listyorini.alj@bio.um.ac.id
}

\begin{abstract}
The white-bellied sea eagle, Haliaeetus leucogaster, is one of the top predators living in the coastal area of Indonesia. This species has the range of distribution in all across Indonesian archipelago. However, this raptor population decreases particularly in the Java southern seas due to illegal hunts and the decreasing quality of their natural habitat. Meanwhile, this species is still poorly studied in Indonesia. This research focuses on the identification of Haliaeetus leucogaster by means of morphometrical analysis in regards to the conservation of this species. The method used in this research is by measuring morphometrical characteristics according to Rahmat (2009) including wing span, body weight, total length, total wing length, wing width, patagial width tail length, tarsus length and depth, talons with claws and without claws, claws, culmen with cere and without cere, culmen height and width, inter-pupil distance, iris color, primairy wing feather number, secondary wing feather number and the number of tail feathers.
\end{abstract}

Keywords: Haliaeetus leucogaster, morphological characteristics

\section{INTRODCTION}

The white-bellied sea eagle, Haliaeetus leucogaster, is one of the top-order predator in coastal environment. This species is recognized as indicator species by which the wilderness quality and environmental integrity are measured (Dennis et al., 2011). Meanwhile, this species population, particularly in Javan southern coastline, is decreasing due to illegal hunts and trading, deforestation and other human activities. Haliaeetus leucogaster distributes all across Indonesian archipelago, Australian coastal areas and the Philipines. However, the size, appearance, and abundance of this species in the densely populated coastal areas are still poorly studied (Debus, 2008).

To give a better understanding about this species as one of the conservation effort, this research identifies the White-bellied Sea Eagle, Haliaeetus leucogaster, by means of morphometrical analysis by measuring morphometrical characteristics according to Rahmat (2009).

\section{MATTERIALS AND METHODS}

The sample of this research is a ten-year-old white-bellied sea eagle taken by a hunter from a reef island off the southern coast of Trenggalek in around 2004. The sample has been under domestication for 9 years in Gedangsewu, Tulungagung Regency. The identification is done by examining the morphological characteristics and measuring several parts that become the specific identification keys according to Rahmat (2009). The measurement is done upon the wing span, body weight, total length, total wing length, wing width, patagial width tail 
length, tarsus length and depth, talons with claws and without claws, claws, culmen with cere and without cere, culmen height and width, inter-pupil distance, iris color, primary wing feather number, secondary wing feather number and the number of tail feathers. The morphometrical data is compared to the holotype.

\section{RESULT AND DISCUSSION}

The white-bellied sea eagle that is examined in this research is a ten-year-old male called Asa. The body is mostly covered in white and grey. In the dorsal part of the body, the white feathers cover the chin, throat, breast, belly, thigh, flank up to the tail. On the dorsal part of the body, the white feathers cover all over the forehead and hindneck, while on the back until rump is covered in grey. The dorsal part of the tail consists of two colors; black at the base up to the middle part of the tail and white from the rest part to the the very end of the tail. The White-bellied sea eagle has a tough solid grey beak with darker colour at the tip of it. The nostril at the base of the culmen is wide. The iris color is dark brown with black pupil. this species shares a common characteristic with another eagle species that is the "eyebrow" called a supercilliary ridge. this eyebrow prevents glare and protects from wind and dust (Chewonki, 2013). The primary wing feathers are strong and are lesser than the other wing feathers. The base of the feather is grey with darker color at the tip of each. The secondary wing feathers have the darker grey color compared to the tersier wings. At the tarsus until the toes, yellow scales cover the skin.

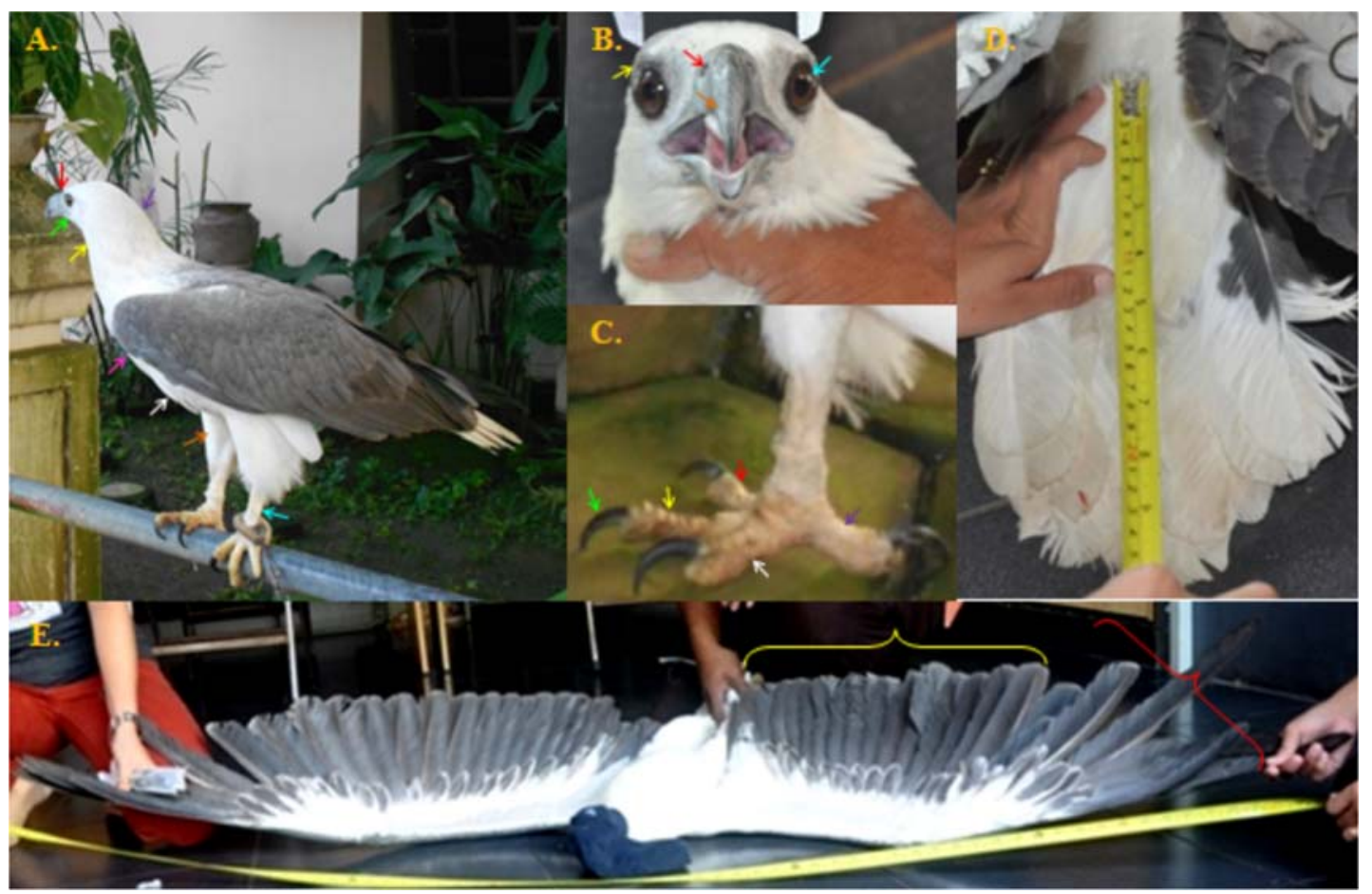

Figure 1. A. whole body, red arrow: forehead; green arrow: chin; yellow arrow: throat; pink arrow: breast; white arrow: belly; brown arrow: thigh; blue arrow: tarsus; purple arrow: hindneck. B. head structure, blue arrow: iris; red arrow: cere; brown arrow: bill; yellow arrow: "eyebrow". C. leg structure, purple arrow: hind toe; white arrow: inner toe; yellow arrow: middle toe; red arrow: outer toe; green arrow: claw. D. tail. E. ventral structure of wing, red bracket: primary wing; yellow bracket: secondary wing. 
Asa's morphometrical characteristics presented in Table 1 is compared to Charles an adult male white-bellied sea eagle which was released on September, $27^{\text {th }} 2007$ in Bantul Lake Area, Kintamani (Wiwoho et al., 2007). The general comparison between Asa and the holotype, Charles, shows that Asa is much bigger than Charles in some parts of the body. Those parts includes the body weight, total wing length, wing span, wing width, patagial width, tail length, tarsus depth, talons with claws, claws hind toe, claws middle toe, culmen without cere, culmen with cere, culmen height, culmen width and inter-pupil distance. Meanwhile, some other parts are smaller. Those are the total length, tarsus length, talons without claws, claws inner toe, and claws outer toe. Thus, in general, Asa is bigger than Charles. Based on the morphometrical analysis done in this research, it is concluded that Asa belongs to the species of Haliaeetus leucogaster.

Table 1. Morphometrics Measurement Data

\begin{tabular}{llcc}
\hline \multicolumn{1}{c}{ Morphometrics Parameter } & Asa & $\begin{array}{c}\text { Charles } \\
\text { (Holotype) }\end{array}$ \\
\hline Body weight & & $2,9 \mathrm{~kg}$ & $1,9 \mathrm{~kg}$ \\
Total length & & $67 \mathrm{~cm}$ & $69 \mathrm{~cm}$ \\
Total wing length & & $87 \mathrm{~cm}$ & $80 \mathrm{~cm}$ \\
Wing span & & $190 \mathrm{~cm}$ & $179 \mathrm{~cm}$ \\
Wing width & & $56,5 \mathrm{~cm}$ & $31 \mathrm{~cm}$ \\
Patagial width & & $28,5 \mathrm{~cm}$ & $9,5 \mathrm{~cm}$ \\
Tail length & & $26,1 \mathrm{~cm}$ & $23 \mathrm{~cm}$ \\
Tarsus length & with claws & $7,15 \mathrm{~cm}$ & $9,3 \mathrm{~cm}$ \\
Tarsus depth & without claws & $15,52 \mathrm{~cm}$ & $1,2 \mathrm{~cm}$ \\
Talons & hind toe & $3,60 \mathrm{~cm}$ & $11,4 \mathrm{~cm}$ \\
& inner toe & $3,16 \mathrm{~cm}$ & $8,9 \mathrm{~cm}$ \\
Claws & middle toe & $2,76 \mathrm{~cm}$ & $3,3 \mathrm{~cm}$ \\
& outer toe & $2,25 \mathrm{~cm}$ & $3,2 \mathrm{~cm}$ \\
& without cere & $4,34 \mathrm{~cm}$ & $2,5 \mathrm{~cm}$ \\
& with cere & $5,48 \mathrm{~cm}$ & $3,6 \mathrm{~cm}$ \\
Culmen & height & $2,92 \mathrm{~cm}$ & $4,5 \mathrm{~cm}$ \\
& width & $1,89 \mathrm{~cm}$ & $1,6 \mathrm{~cm}$ \\
Inter-pupil distance & & $4,52 \mathrm{~cm}$ & $4,3 \mathrm{~cm}$ \\
Iris Colour & & Dark brown & Light brown \\
Primairy wing feather number & Right & 5 & \\
Secondary wing feather number & Right & 19 & \\
Number of tail feathers & Left & 19 & \\
\hline & & 11 & \\
& & &
\end{tabular}

\section{REFFERENCES}

Chewonki. 2013. Birds of Prey The Habits and Adaptation of Maine's Raptors. Maine: Chewonki Foundation.

Debus, S.J.S. 2008. Biology and Diet of the White-bellied Sea-Eagle Haliaeetus leucogaster Breeding in Northern Inland New South Wales. Australian Field Ornithology 2008, 25, 165-193

Dennis, T. E., R.R. Mclntosh, and P.D. Shaughnessy, P. D., 2011. Effects of Human Disturbance on Productivity of White-bellied Sea-Eagles (Haliaeetus leucogaster). Emu, 2011, 111, 179-185. 
4. Rahmat, A. 2009. Pengukuran karakter Morfometrik pada Burung Pemangsa. Makalah disajikan pada Pelatihan Handling, Morfometri, Marking dan Monitoring Raptor Pasca Release, Raptor Indonesia, Juni 2009.

5. Wiwoho, J., O.P. Basuki, and R. Huda, R. 2007. Laporan Program Pelepasliaran Elang Laut Perut Putih (Haliaeetus leucogaster) di kawasan Danau Bantur. Bali: Pusat Penyelamatan Satwa Bali. 